\title{
Individual distance-independent girth increment model for Douglas-fir in southern Belgium
}

\author{
Arnaud Monty, Philippe Lejeune, Jacques Rondeux
}

Unit of Forest and Nature Management, Gembloux Agricultural University, passage des Déportés 2, B-5030 Gembloux, Belgium

\begin{abstract}
An individual distance-independent girth increment model for pure stands of Douglas-fir (Pseudotsuga menziesii (MIRB.) FRANCO), comprising two equations, is presented. The data used to fit the model were collected from 1007 trees in 42 plots installed in regularly stocked and even-aged stands located in Wallonia (southern Belgium). Both equations predict girth increment from individual girth, dominant height, basal area per hectare, stand mean girth and variables linked to site fertility. These last variables are the site index $\mathrm{H} 50$ in the first equation, and a combination of mean annual rainfall and altitude in the second. The coefficient of determination ranges from 0.434 to 0.481 and the root mean square error ranges from 0.7857 to $0.8194 \mathrm{~cm}_{\text {year }^{-1}}$. Estimated increments of 224 Douglas-fir trees in 12 different and independent stands were used to validate the model, which is expected to provide reliable predictions for most of the pure Douglas-fir stands located in the study area.
\end{abstract}

Keywords: Pseudotsuga menziesii (MIRB.) ; FRANCO; Growth model; Girth increment

\section{Introduction}

Pure stands of Douglas-fir (Pseudotsuga menziesii (MIRB.) FRANCO) cover about 11,000 ha in Wallonia (southern Belgium), and may reach 15,000 ha in a few decades, given the extension of young mixed Douglas-fir spruce stands, which should become pure after one or two thinnings (Lecomte et al., 2003). Douglas-fir was brought to Belgium in the late 19th century, but large-scale plantations only started after the middle of the 20th century (Crahay, 1900; Anonymous, 1920; AFOCEL, 1997; Joris, 1975). Before 1964 genetic provenance was generally unknown and phenotypes were very variable. Nowadays the genetic quality of the plants is far superior (Nanson, 2004), and P. menziesii offers several advantages that appeal to foresters: it has a very high growth rate, it provides high added-value timber (especially after the first thinning) and it may replace spruce (Picea abies KARST.) advantageously in many places in Belgium. However, Douglas-fir has mostly been planted on fertile, appropriate soil, with suitable drainability, unlike spruce, which has been planted in a very broad range of sites (Claessens et al., 1996). In Belgium silviculture applied to conifers still strongly emphasises spruce stand management, and often maintains higher densities than in other European countries (e.g..France). The productivity of Belgian Douglas-fir stands was studied by Claessens et al. (1996), who gave productivity curves, and by Rondeux and Thibaut (1996), who constructed yield tables based on a stand model. Through a variabledensity yield table, this model presented the silvicultural pathways for Douglas-fir in Belgium, but it considered only average stand growth and so could not estimate the effects of a wide range of silvicultural treatments (Rondeux et al., 1991). The key to successful management of Douglas-fir stands is a proper understanding of growth processes. One of the most appropriate methods to simulate and evaluate silvicultural alternatives is based on predicting the basal area, diameter or girth increment of individual trees (Biging and Dobbertin, 1992; Lee, 1967; Ek and Monserud, 1974; Monserud, 1975; Burkhart et al., 1987; Pukkala, 1989; Monserud and Sterba, 1996; Schroder et al., 2002; Pretzsch, 2002). Much research has been done on modelling the growth of Douglas-fir throughout its natural dispersion and introduction area (Newnham, 1964; Arney, 1972; Mitchell, 1975; Curtis et al, 1981; Wykoff et al., 1982; Wykoff, 1986; Ottorini, 1991; Wimberly and Bare, 1996; Hann and Hanus, 2002; Hann et al., 2003).

In even-aged stands growth modelling, the effect of site quality is often accounted for by using site index or numerical expression which relates stand dominant height to stand age (Lee et al, 2004; Diéguez-Aranda et al, 2006).

Another approach assesses site quality from environmental causal factors (Porte and Bartelink, 2002; Sterba and Monserud, 1997). Some authors are also using multiple regression analysis with height or site index as the dependent variable and a set of environmental characteristics such as edaphic, climatic, topographic, etc. (Louw and Scholes, 2006) as the independent variables. 
The purpose of the present study is to develop for pure Douglas-fir stands in Wallonia, an individual, distanceindependent periodic annual girth increment model based on available dendrometrical data derived mainly from girth and top height.

The two previous approaches have been used for expressing site quality effect: site index itself and specific site factors in order to avoid the problem of site index estimation when age is unknown. For the latter only variables that were available from regional GIS databases have been considered such as elevation, main soil characteristics and average climatic parameters. Such a limitation has been decided in order to make the resulting model easily usable by forest managers (Chumachenko et al., 2003).

Table 1: Stand characteristics of construction and validation data sets

\begin{tabular}{|c|c|c|c|c|c|c|c|c|}
\hline \multirow[t]{3}{*}{ Variable } & \multicolumn{4}{|c|}{ Model construction } & \multicolumn{4}{|c|}{ Model validation } \\
\hline & \multirow[b]{2}{*}{ Mean } & \multicolumn{2}{|c|}{42 plots, 1007 trees } & \multirow[t]{2}{*}{$\mathrm{CV}(\%)$} & \multicolumn{3}{|c|}{12 plots, 224 trees } & \multirow[t]{2}{*}{ CV (\%) } \\
\hline & & Min & Max & & $\overline{\text { Mean }}$ & Min & Max & \\
\hline$\overline{\text { Age (year) }}$ & 32 & 13 & 64 & 38.2 & 34 & 14 & 64 & 44.4 \\
\hline Girth $(1.3 \mathrm{~cm})$ & 88.3 & 22.0 & 215.0 & 42.0 & 87.2 & 22.0 & 246.0 & 49.0 \\
\hline Mean girth $(\mathrm{cm})$ & 89.0 & 36.4 & 197.7 & 39.0 & 87.3 & 39.1 & 169.4 & 43.7 \\
\hline Top height (m) & 23.5 & 9.4 & 34.9 & 30.1 & 23.0 & 9.9 & 34.9 & 36.1 \\
\hline Density (tree/ha) & 905 & 186 & 2586 & 76.9 & 831 & 140 & 1500 & 54.2 \\
\hline Basal area $\left(\mathrm{m}^{2} \mathrm{ha}^{-1}\right)$ & 36.3 & 10.6 & 74.3 & 29.3 & 36.5 & 18.4 & 71.8 & 42.1 \\
\hline Site index $(\mathrm{m})$ & 33 & 20 & 40 & 8.3 & 32 & 26 & 36 & 6.2 \\
\hline
\end{tabular}

\section{Materials and methods}

The main body of data come from 40 permanent plots measured at intervals of 3-6 years from 1978 to 2004, and concerning a total of 1032 trees. Additional data was obtained from 14 plots of the permanent regional forest inventory (Rondeux and Lecomte, 2001), measured again in 2005 (intervals of 3-8 years) to obtain increment data on 199 trees. The plots were distributed in southern Belgium from 5002'27.26"E to 50 $13^{\circ} 47.3^{\prime \prime} \mathrm{E}$ and from $5^{\circ} 31^{\prime} 0.69^{\prime \prime} \mathrm{N}$ to $5^{\circ} 17^{\prime} 41.32^{\prime \prime} \mathrm{N}$, roughly corresponding to the Douglas-fir presence area in Belgium. All plots were in even-aged and pure or almost pure stands (more than $80 \%$ of basal area represented by Douglas-fir), and the decrease in the number of trees per hectare between two measurements, at least 3 years, never exceeded $20 \%$. In each plot, tree girth was measured at $1.3 \mathrm{~m}$ above the ground with a tape and dominant height was estimated from VERTEX ${ }^{\circledR}$ height measurements (Rondeux and Pauwels, 1997) on largest diameter trees. Plots ranged from 50 to $1000 \mathrm{~m}^{2}$ in area and contained 6-47 Douglas-fir trees.

The data was split into two parts: 12 plots (including an amount of 224 trees) were randomly chosen for the model validation, while the 1007 remaining trees (from 42 other plots) were used for the model construction. Table 1 gives stand characteristics for both sets of data.

Multiple least-square estimation was used to build the growth model. First, different variables and combinations of variables were tested using a STEPWISE procedure to find those most closely correlated with girth increment. Second, a selection was made considering several aspects, such as model structure, biological implications of each term (e.g., sign of the estimates), variable availability among existing inventories and validation possibilities.

\subsection{Dendrometrical growth model}

The dependent variable of the model was the girth increment outside bark at $1.3 \mathrm{~m}$ from ground level $\left(\mathrm{i}_{\mathrm{c}}, \mathrm{cm}\right.$ year $\left.^{-1}\right)$. The tested variables for model building were linked to stand competition, stand development, stand structure, site fertility, individual tree size and individual social ranking. Stand competition was measured by density (estimated number of trees per hectare $\mathrm{N})$, basal area per hectare $\left(\mathrm{G}, \mathrm{m}^{2} \mathrm{ha}^{-1}\right)$ and the crown competition factor (CCF) of Krajicek et al. (1961). Stand development was represented by the age (Age, year), the dominant height $($ Hdom, $\mathrm{m})$, the dominant girth $(\mathrm{Cdom}, \mathrm{cm})$ and the mean stand girth $(\mathrm{c}, \mathrm{cm})$. The structure of the stand was characterized by the girth variance $\left(\mathrm{VAR}, \mathrm{cm}^{2}\right)$. Site fertility was described by the site index $(\mathrm{H} 50, \mathrm{~m})$, 
defined as dominant height reached at 50 years. The individual tree size was represented only by the girth (c, $\mathrm{cm}$ ), measured at $1.3 \mathrm{~m}$ from ground level, given available data. Individual social ranking of each tree is fundamental for an individual tree growth model. The different non-spatial indices that were considered for model construction are presented below:

$$
\begin{aligned}
& \text { Crel_ } \bar{c}_{\mathrm{q}}=\frac{c}{\bar{c}_{\mathrm{q}}}, \quad \text { Crel_Cdom }=\frac{c}{\text { Cdom }}, \quad \text { Crel_ } \bar{c}=\frac{c}{\bar{c}}, \\
& \text { Crel_Hdom }=\frac{c}{\text { Hdom }}, \quad E P G=\frac{c}{4 \pi G}, \\
& \text { gsup }=\frac{\left(\sum g>g_{s}\right) \times 10,000}{\text { surf }}, \quad \text { gsup_rel }=\frac{\text { gsup }}{G}
\end{aligned}
$$

where $\bar{c}_{\mathrm{q}}$ is the quadratic mean stand girth $(\mathrm{cm}), g$ the individual basal area $\left(\mathrm{m}^{2}\right)$ at $1.3 \mathrm{~m}$ above ground level, surf the plot area $\left(\mathrm{m}^{2}\right)$ and $\mathrm{s}$ is the notation for the considered tree.

\subsection{Integration of ecological variables}

Available ecological quantitative data were considered as potential-independent variables in the model: altitude (ALT, m), soil depth (SD, cm), average annual rainfall (RAIN, mm year ${ }^{-1}$ ) and vegetation period (PVEG, day year $^{-1}$ ) were set, along with the dendrometrical variables, in the STEPWISE regression. ALT was derived from a digital elevation model, SD from the digital soil map of Wallonia (Veron et al., 2005), and PVEG and PLMOY from climatic maps of Poncelet and Martin (1947), through the use of a GIS (Lejeune, 1993). The potential benefit of these variables was to replace the site index H50 in the regression equation. This stand parameter was not always known with precision, and often required the use of the productivity curves of Claessens et al. (1996). A site index-independent equation was thus needed if H50 appeared in the main equation.

Residuals of the regression equation were then analysed with a one-way ANOVA, the tested factor being the main regions of southern Belgium. These qualitative data distributed stands, from North to South, in "Silty area", "Condroz", "Fagne and Famenne", "Basse Ardenne", "Haute Ardenne", "Moyenne Ardenne" and "Jurassic region". The database was unfortunately unbalanced for these variables, and regions were therefore aggregated as "Condroz", "Basse Ardenne", "Haute and Moyenne Ardenne" and "Others" to contain comparable numbers of trees.

\subsection{Model evaluation and validation}

The model was quantitatively evaluated by examining the distribution of residuals, and by testing for bias and precision to determine the accuracy of model estimations (Vanclay, 1994; Soares et al., 1995; Gadow and Hui, 1998; Mabvurira and Müna, 2002). Absolute and relative bias and root mean square error were calculated as follows:

$$
\begin{aligned}
& \text { bias }=\frac{\sum\left(y_{i}-\hat{y}_{i}\right)}{n}, \quad \text { bias } \%=100 \frac{\sum\left(y_{i}-\hat{y}_{i}\right) / n}{\sum \hat{y}_{i} / n} \\
& \operatorname{RMSE}=\left[\frac{\sum\left(y_{i}-\hat{y}_{i}\right)^{2}}{n-1}\right]^{1 / 2}, \\
& \text { RMSE } \%=100\left[\frac{\sum\left(y_{i}-\hat{y}_{i}\right)^{2} /(n-1)}{\sum \hat{y}_{i} / n}\right]^{1 / 2}
\end{aligned}
$$

where $y_{i}$ is the observed girth increment value, $\hat{y}_{i}$ the predicted girth increment value and $n$ is the number of trees.

The model was also tested for validation using the set of independent increment data for 224 trees (12 independent plots). The validation needs the residuals of the model on this database, calculated as the difference between the observed and the estimated increment, to be on average equal to zero. Also, the re-calculated coefficient of determination $\left(R^{2}\right)$, defined as the complement to unity of the quotient of residual variance and 
observed variance, must be sufficiently close to that calculated at construction (Dagnelie, 1992). Finally, correlation of residuals of the validated model with some non-entering variables was calculated and is discussed below.

\section{Results}

\subsection{Dendrological growth model}

Several models were set up by STEPWISE regression of $i_{c}$ (plain or transformed) by more than 40 independent variables of interest (plain and transformed). The selected equation (Eq. (1)), presented in Table 2 made sense from a biological approach point of view (including site fertility and stand density variables). It was also best for validation on the independent database (see below). Its adjusted coefficient of determination was equal to 0.481 . When girth increment estimations were negative, they were replaced by a null value. Fortunately, this concerned very few data $(0.6 \%$ of the construction data set).

The selected variables entering the multiple regression equation indicate influence of stand competition, site fertility, stand development and social ranking; but not directly individual tree size or stand structure. It is to be noted that the model is age-independent, as stand development is expressed by mean girth.

Partial coefficient of determination $\left(R_{\text {partial }}^{2}\right)$ for independent variables measures the marginal contribution of each variable when all the remaining variables are already in the equation. Competition level in the stand is expressed by $\mathrm{G}^{-1}$, showing an increment reduction when basal area is large. This variable explains a smaller part of the increment variability $\left(R_{\text {partial }}^{2}=0029\right)$ than $\ln (\mathrm{c} /$ Hdom $)$, which expresses the social ranking of each tree in a stand and is the most explicative variable $\left(R_{\text {partial }}^{2}=0.396\right)$. For a given dominant height, girth increment will be greater when trees are bigger, but the relation is not linear, as logarithmic transformation is used. Site index logarithm is moderately explicative, with a partial $R^{2}$ of 0.052 . Stand development, through mean girth, is the least explicative part of the model with a partial $R^{2}$ of only 0.003 . Girth increment is positively correlated to site fertility, and decreases with mean girth.

\subsection{Integration of ecological variables}

As the site index appeared in the dendrological model, a second equation was built in which the site index was replaced by direct ecological quantitative variables. These variables were included in the new equation using STEPWISE selection, with other dendrometrical variables already present in the first model. Only average annual rainfall (PLMOY) and altitude (ALT) were found to be significant with logical estimate signs. The second equation is presented in Table 3 (Eq. (2)). Its adjusted coefficient of determination is equal to 0.434.

Table 2: Equation form, parameter estimates and related statistics for dendrometrical growth model ${ }^{a}$

\begin{tabular}{|c|c|c|c|c|c|c|c|c|}
\hline \multicolumn{9}{|l|}{ Equation } \\
\hline \multicolumn{8}{|c|}{$i_{\mathrm{C}}=\alpha 0+\alpha 1 \ln \left(\mathrm{cHdom}^{-1}\right)+\alpha 2 \ln (\mathrm{H} 50)+\alpha 3 \mathrm{G}^{-1}+\alpha 4 \overline{\mathrm{c}}$} & \multirow{2}{*}{$\begin{array}{l}\text { Eq. (1) } \\
\text { VIF }\end{array}$} \\
\hline Variable & Parameter & Estimate & & S.E. & $\mathbf{t}$ & $p>t$ & $\boldsymbol{R}_{\text {partial }}^{2}$ & \\
\hline Intercept & $\alpha 0$ & -12.64100 & & 1.1410000 & -11.08 & 0.000 & & \\
\hline $\ln \left(\mathrm{cHdom}^{-1}\right)$ & $a 1$ & 2.930600 & & 0.1059000 & 27.68 & 0.000 & 0.396 & 1.3 \\
\hline $\ln (\mathrm{H} 50)$ & $a 2$ & 3.048200 & & 0.3051000 & 9.990 & 0.000 & 0.052 & 1.2 \\
\hline $\mathrm{G}^{-1}$ & $a 3$ & 23.84700 & & 3.1990000 & 7.460 & 0.000 & 0.029 & 1.3 \\
\hline$\overline{\mathrm{c}}$ & $\alpha 4$ & -0.002259 & & 0.0008901 & -2.540 & 0.011 & 0.003 & 1.5 \\
\hline Source & d.f. & SS & MS & $\mathbf{F}$ & $p>\mathbf{F}$ & Adjusted $\mathbf{R}^{2}$ & \multicolumn{2}{|c|}{ Residual S.D. } \\
\hline Regression & 4 & 577.960 & 144.49 & 233.29 & 0.000 & 0.481 & \multicolumn{2}{|l|}{0.7870} \\
\hline Error & 1002 & 620.580 & \multicolumn{6}{|l|}{0.6200} \\
\hline Total & 1006 & 1198.54 & & & & & & \\
\hline
\end{tabular}

${ }^{a}$ S.E.: standard error; t: statistic for testing the null-hypothesis that a single parameter is zero; $p>t$ : probability that a t-statistic would obtain a greater value than that observed given that the true parameter is zero; VIF: variance inflation factor; d.f.: degrees of freedom; SS: sum of squares; MS: mean square; F: statistic for testing the null-hypothesis that all parameter are zero except for the intercept; $p>\mathrm{F}$ : probability of getting a greater F-statistic than that observed if the null-hypothesis is true; residual S.D.: residual standard deviation. 
The analysis of the residuals of both models revealed that the qualitative ecological variable affected them (oneway ANOVA: d.f. $=3 ; \mathrm{F}=38.39 ; \mathrm{p}=0.000$ and d.f. $=3 ; \mathrm{F}=46.81 ; \mathrm{p}=0.000$, respectively for Eqs. (1) and (2)) after aggregation of ecological areas. The "Basse Ardenne" region showed a significantly larger mean girth increment than all the others for both models. The "Condroz" region came second (significantly different from first and third, for both models, at the 0.05 level), and was followed by "Moyenne and Haute Ardenne", then by "Others". This result has to be interpreted with caution, given the structure of the data set. Age classes and silvicultural conditions were not evenly distributed among regions, and some very similar plots were located very close together. For example the region "Basse Ardenne", which was found to present the highest girth increment, was mainly represented by young stands, and four plots younger than 25 years were found clustered in a $1.5 \mathrm{~km}^{2}$ area. Representativity of each region was therefore not constant, and differences can be explained by reasons other than ecological area.

\subsection{Model evaluation and validation}

The residuals of both models displayed, globally, a good fit for most girth classes as shown in Fig. 1. No clear heteroscedastic tendency appears in Graphs $\mathrm{a}$ and $\mathrm{b}$ of this figure, although slightly higher residuals correspond to small trees. Respectively for Eqs. (1) and (2), the absolute bias values were -0.0457 and $0.00369 \mathrm{~cm}^{2} \mathrm{ear}^{-1}$, and the RMSE were 0.7857 and $0.8193 \mathrm{~cm}_{\text {year }}{ }^{-1}$. The relative bias was equal to $-1.98 \%$ and $0.16 \%$ and the relative RMSE value was $34.0 \%$ and $36.3 \%$, respectively for Eqs. (1) and (2). Seeing that measurements are generally made to the nearest centimetre, and if girth periodic increments are considered over a sufficiently long time (3 years or more), these values seem reasonable. The variance inflation factors (VIFs) shown in Tables 2 and 3 to quantify multicollinearity are all below the critical threshold of 5 suggested by Van Laar (1991). Multicollinearity among the predictors is thus considered negligible (see Marquardt, 1970; Pacheco Marques, 1991).

Considering parameter estimates in Eq. (1) it was found that when the site index (H50) increased by $6 \mathrm{~m}$, from the third to the first productivity class (Claessens et al., 1996), all the other variables remaining constant, girth increment increased by $0.556 \mathrm{~cm}$ year $^{-1}$. For the social rank term, a double variation sometimes appeared depending on $\mathrm{c}$ and Hdom. However, in a single stand, e.g., a 50-year-old stand with Hdom equal to $33 \mathrm{~m}$ (mean productivity class), a $150 \mathrm{~cm}$ tree would grow by $1.188 \mathrm{~cm}_{\text {year }}^{-1}$ more than a $100 \mathrm{~cm}$ tree considering this term. This indicates a strong influence of social rank on Douglas-fir growth, as is generally observed in situ. Stand competition, through $\mathrm{G}^{-1}$, enhanced increment variations, depending on basal area extreme values. Thus these variations may be greater in old stands, where $G$ depends on more numerous thinnings. Considering extreme values in the construction database (Table 1), 10.6 and $74.3 \mathrm{~m}^{2} \mathrm{ha}^{-1}$, the stand competition term induced an estimated girth increment variation of $1.925 \mathrm{~cm} \mathrm{year}^{-1}$. Nevertheless, such differences in $\mathrm{G}$ are not common over a few years. Mean girth induced an increment variation of $0.365 \mathrm{~cm}_{\text {year }}{ }^{-1}$. Dendrometrical variables in Eq. (2) enhanced variations in girth increment estimation that were comparable to those in Eq. (1) given that estimates belong to the same range of values. The new variables, PLMOY and ALT, induced increment variations of 0.513 and $0.414 \mathrm{~cm} \mathrm{year}^{-1}$, respectively, extreme values in the construction database being 758 and $1200 \mathrm{~mm}$ for average annual rainfall and 140 and $510 \mathrm{~m}$ for altitude.

Both models were used to estimate girth increments of the 224 validation database trees, and validation was successful. Residuals had a normal distribution (Ryan and Joiner test: $p>0.1$ for both equations) and were on average significantly equal to zero (t-test; $p=0.055$ and 0.692 , respectively for (1) and (2)). The re-calculated coefficients of determination (when using the models to predict increments of the 224 validation trees) were 0.539 for (1) and 0.544 for (2), which are even higher than for the construction data set. It is to be noted that increments estimations were positive for all 224 trees.

Correlations were also calculated between residuals of both equations and some non-entering variables, which are linked to stand development and stand structure, and did not appear in the model. The Pearson's correlation coefficients showed that the only significant correlations for (1) are with girth variance and stand structure, but the coefficient is very low $(r=0.072)$. For $(2)$, the only significant correlation is with the stand age, but the coefficient is also very low ( $r=-0.091)$ and the linear relation between residuals and stand age is very loose. The age-independent model was thus appropriate to account for Douglas-fir girth increment. 
Table 3: Equation form, parameter estimates and related statistics for growth model with ecological variables ${ }^{a}$

\begin{tabular}{|c|c|c|c|c|c|c|c|c|}
\hline \multicolumn{9}{|l|}{ Equation } \\
\hline \multicolumn{7}{|c|}{ 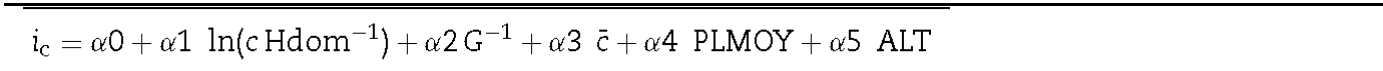 } & \multirow[b]{2}{*}{$\mathbf{R}_{\text {partial }}^{2}$} & \multirow{2}{*}{$\begin{array}{l}\text { Eq. (2) } \\
\text { VIF }\end{array}$} \\
\hline Variable & Parameter & & Estimate & S.E. & $\mathbf{t}$ & $p>t$ & & \\
\hline Intercept & $\alpha 0$ & & -2.08380 & 0.3025000 & $\begin{array}{l}-6.89 \\
\end{array}$ & 0.000 & & \\
\hline $\ln \left(\mathrm{cHdom}^{-1}\right)$ & $a 1$ & & 2.753100 & 0.1099000 & 25.06 & 0.000 & 0.354 & 1.3 \\
\hline $\mathrm{G}^{-1}$ & $a 2$ & & 17.28700 & 3.2630000 & 5.300 & 0.000 & 0.016 & 1.2 \\
\hline$\overline{\mathrm{c}}$ & $a 3$ & & -0.004184 & 0.0009316 & -4.490 & 0.000 & 0.011 & 1.6 \\
\hline PLMOY & $\alpha 4$ & & 0.00116 & 0.0003623 & 3.210 & 0.001 & 0.006 & 2.6 \\
\hline ALT & $\alpha 5$ & & -0.001118 & 0.0004330 & -2.580 & 0.010 & 0.004 & 2.5 \\
\hline Source & d.f. & SS & MS & $\mathbf{F}$ & $p>\mathbf{F}$ & Adjusted $R^{2}$ & \multicolumn{2}{|c|}{ Residual S.D. } \\
\hline Regression & 5 & 523.130 & 104.63 & 155.06 & 0.000 & 0.434 & \multirow{3}{*}{\multicolumn{2}{|c|}{0.8214}} \\
\hline Error & 1001 & 675.410 & 0.6700 & & & & & \\
\hline Total & 1006 & 1198.54 & & & & & & \\
\hline
\end{tabular}

${ }^{a}$ S.E.: standard error; t: statistic for testing the null-hypothesis that a single parameter is zero; $p>t$ : probability that a t-statistic would obtain a greater value than that observed given that the true parameter is zero; VIF: variance inflation factor; d.f.: degrees of freedom; SS: sum of squares; MS: mean square; F: statistic for testing the null-hypothesis that all parameter are zero except for the intercept; $p$ F: probability of getting a greater F-statistic than that observed if the null-hypothesis is true; residual S.D.: residual standard deviation.

Fig. 1: Residuals (calculated as observed values minus predicted values) obtained for Eq. (1) (a) and Eq. (2) (b) vs. girth.
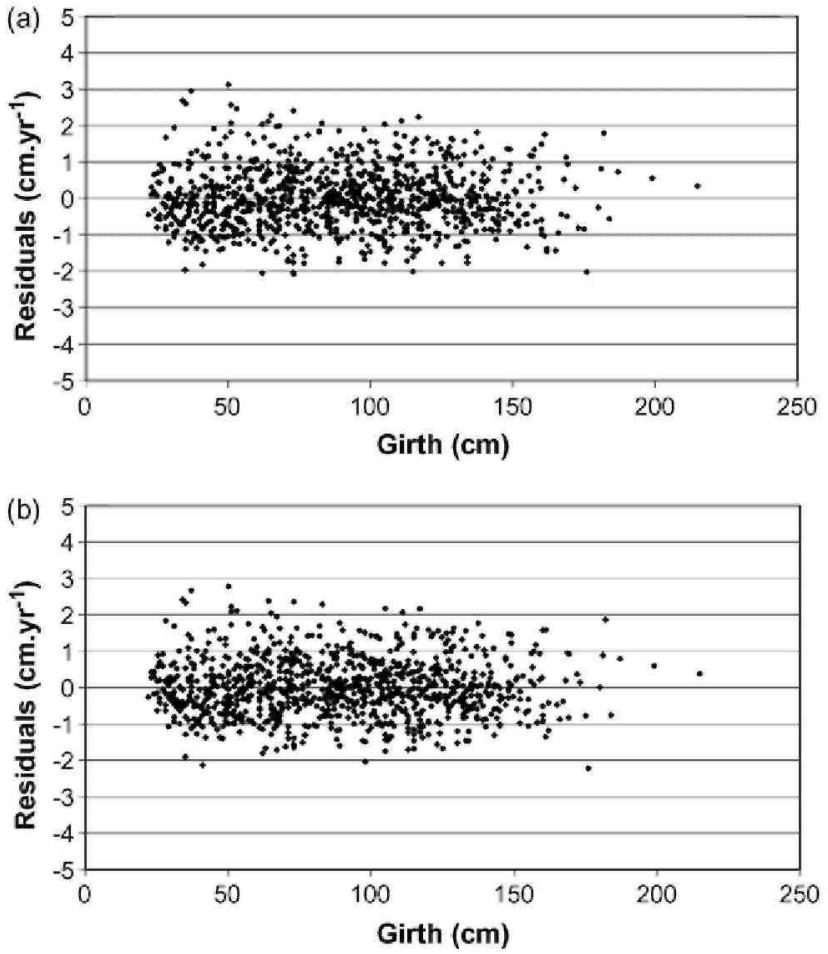

\section{Discussion}

The selected variables entering the two models are common and easily available from a traditional forest inventory. Age-independence is an advantage when simulating the development of any stand, as plantations are sometimes spread over several years (in-fillings). The site index (H50) is the only variable that can be problematic, for instance in young stands, because its estimation depends on the precision of the productivity 
curves (Claessens et al., 1996) and of the measured dominant height. Here the problem is avoided by the possibility of adapting the girth increment predictions to the available data on ecological conditions: either site index or ecological variables found from climatic and topographic maps. Replacing H50 by ecological variables, we found that site fertility could, in our case, be partially linked to annual average rainfalls and altitude. In a specific study on this topic, conducted in middle-elevation regions of the Massif Central area in France, Curt et al. (2001) found strong correlation between site index (H25, here defined as the dominant height reached at age 25 years) and (1) soil nutrient status and (2) soil moisture regime. However, in order to model the site index, they used elevation and water seepage index as independent variable with available water storage capacity, soil nutrient status and exposure. In view of our available data, we can thus underline the correspondence between this study and ours.

The data set in this study had some limitations that caused problems in the modelling work and may also affect model predictions. For instance, the data was insufficiently representative of some ecological regions, making it impossible to adapt predictions to particular areas and possibly leading to overestimation or underestimation in regions underrepresented in the data set. In addition, model predictions are only defined in the range of variation of the construction and validation data that correspond to trees of girth ranging from 22 to $215 \mathrm{~cm}$. In terms of age, the model predictions are defined between 13 and 64 years. Ancient stands are thus not concerned by this study, which is no problem because in such stands silvicultural decisions are based more on timber prices and regeneration possibilities than on quantitative pathways.

Compared with other growth models developed for Douglas-fir, our models present a moderate precision (Newnham, 1964; Arney, 1972; Mitchell, 1975; Wykoff et al., 1982; Wykoff, 1986; Ottorini, 1991; Wimberly and Bare, 1996; Hann and Hanus, 2002; Hann et al., 2003). The accuracy of the growth models developed here has to be viewed within the constraints of the data. The procedure applied in the calculation of annual increments, based on successive measurements, assumes that tree growth is constant during the interval between measurements. However, growth conditions (e.g., annual rainfall) may vary over time and between years. Indeed, tree growth is not linear even over a single year, which is not taken into account in this study. For instance, the mean annual rainfall that appears in Eq. (2) only limits tree growth during dry periods, like summer, and hardly plays any role during the rest of the year (Zhang et al., 2000).

The accuracy of the models is also linked to their distance-independence, as data prevented the calculation of distance-dependent competition indices. However, the literature suggests that precision gain when using such indices is hardly worth the complexity of measurements needed. Wimberly and Bare (1996), modelling Douglasfir basal area growth on the southwest coast of Vancouver Island, showed that the additional effort and expense needed to obtain spatially referenced stand data for developing empirical forest growth models was not justified. Studies carried out in a variety of other forest types and species have also concluded that spatial competition indices did not greatly improve the fit of basal area, girth and diameter growth models (Pauwels et al., 2003; Biging and Dobbertin, 1995; Tome and Burkhart, 1989; Daniels et al., 1986; Martin and Ek, 1984; Lorimer, 1983). Nevertheless, the main interest of those two models lies in their flexibility of use regarding the nature of the available data: if site index is known, the first model (the most accurate) can be used. Indeed, the equation is age-independent. Otherwise, the second is more appropriate. In this case, site productivity is characterized by basic ecological variables of which values are determined from GIS data disseminated at the regional level. Furthermore, a potential use of the second model consists in its linkage with climatic variables, that prefigures an approach in which the understanding of the dynamics of Douglas-fir should be useful to identify its resilience and vulnerability to changes in climate (Nitschke and Innes, 2008).

\section{Conclusion}

The present study was based on selected data sets dependent on the resources available for the task. An individual age-independent and distance-independent girth periodic annual increment model was built for Douglas-fir pure stands in southern Belgium. Two regression equations are presented. The first one shows an adjusted coefficient of determination of 0.481 and is to be used as a priority. The second one is to be used when the fertility index (H50) is unknown or not precisely known. It was built using direct ecological variables and presents a coefficient of determination of 0.434 . The models can now be integrated in a silvicultural simulation software program. This study is the first step towards further research on Douglas-fir growth modelling in Belgium which will extend to mixed stands, especially with spruce, which are more and more prevalent in the area. 


\section{Acknowledgements}

The authors gratefully acknowledge support of the Walloon Region-GRNE/DNF through the 'AccordCadre/Forest research" project. They are particularly grateful to Ir. Hugues Lecomte (Walloon Permanent Forest Resources Inventory, WPFRI) who provided necessary data for this study and to Professor Jacques Hebert for his useful suggestions.

\section{REFERENCES}

AFOCEL, 1997. Le Douglas. AFOCEL, Paris.

Anonymous, 1920. Les douglas de Sibret. Bull. Soc. Roy. For. De Belgique 27, 453-460.

Arney, J.D., 1972. Computer simulation of Douglas-fir tree and stand growth. Ph.D. Thesis. Oregon State University, Corvallis.

Biging, G.S., Dobbertin, M., 1992. A comparison of distance dependent competition measures for height and basal area growth on individual conifer trees. Forest Sci. 38 (3), 695-720.

Biging, G.S., Dobbertin, M., 1995. Evaluation of competition indices in individual tree growth models. Forest Sci. 41 (2), $360-377$.

Burkhart, H.E., Farrar, K.D., Amateis, R.L., Daniels, R.F., 1987. Simulation of Individual Tree Growth and Stand Development in Loblolly Pine Plantations on Cutover, Site-prepared Areas. FWS-1-87. Virg. Polytechn. Inst, and State Univ., Blacksburg.

Chumachenko, S.I., Korotkov, V.N., Palenova, M.M., Politov, D.V., 2003. Simulation modelling of long-term stand dynamics at different scenarios of forest management for coniferous-broad-leaved forests. Ecol. Model. 170, 345-361.

Claessens, H., Thibaut, A., Rondeux, J., 1996. Le douglas en Belgique. Centre de Recherche et de Promotion Forestières, IRSIA, Section Ecologie, Gembloux.

Crahay, N.I., 1900. A propos de quelques résineux de l'Amérique du Nord-Le sapin de douglas. Bull. Soc. Roy. For. De Belgique 8, 340351.

Curt, T, Bouchaud, M., Agrech, G., 2001. Predicting site index of Douglas-fir plantations from ecological variables in the Massif Central area of France. For. Ecol. Manage. 149, 61-74.

Curtis, R.O, Clendenen, G.W., DeMars, D.J., 1981. A new stand simulator for coast Douglas-fir: DFSIM user's guide. General Technical Report PNW-128. USDA Forest Service, Pacific Northwest Forest and Range Experiment Station, Portland, OR.

Dagnelie, P., 1992. Statistiques théoriques et appliqués, tome 1. Les Presses agronomiques de Gembloux, Gembloux.

Daniels, R.F., Burkhart, H.E., Clason, T.R., 1986. A comparison of competition measures for predicting growth of loblolly pine trees. Can. J. For. Res. 16,1230-1237.

Diéguez-Aranda, U., Castedo Dorado, F., Alvarez Gonzalez, J.G, Rojo Alboreca, A., 2006. Dynamic growth model for Scots pine (Pinus syluestris L.) plantations in Galicia (north-western Spain). Ecol. Model. 191, 225-242.

Ek, A.R., Monserud, R.A., 1974. Trials with program FOREST: Growth and reproduction simulation for mixed species even- or unevenaged forest stands, In: Fries, J. (Hrsg.), Growth Models for Tree and Stand Simulation. Royal College of Forestry, Stockholm, Sweden, Research Notes, No. 30.

Gadow, K., Hui, G, 1998. Modelling Forest Development. Faculty of Forest and Woodland Ecology. University of Göttingen.

Hann, D.W., Hanus, M.L., 2002. Enhanced diameter growth-rate for undamaged and damaged trees in southwest Oregon. Research Contribution 39. Forestry Research Laboratory, Oregon State University, Corvallis, OR.

Hann, D.W., Marshall, D.D., Hanus, M.L., 2003. Equations to predict height-to-crown base, five-year diameter growth rate, five-year height growth rate and maximum-size density trajectory for Douglas-fir and western hemlock in the coastal region of the Pacific Northwest. Research Contribution 40. Forest Research Laboratory, Oregon State University, Corvallis, OR.

Joris, D., 1975. Le douglas en Belgique. Bull. Soc. Roy. For. De Belgique 82, 219-274.

Krajicek, J.E., Brinkman, K.A., Gingrich, S.F., 1961. Crown competition-a measure of density. Forest Sci. 7, 35-42.

Lecomte, H., Florkin, P., Morimont, J.P., Thirion, M., 2003. La forêt wallonne: état de la ressource à la fin du XX ${ }^{\mathrm{e}}$ siecle. MRW-DGRNE. Division de la Nature et des Forêts, Jambes. 
Lee, Y, 1967. Stand models for lodgepole pine and limits to their application. Ph.D. Thesis. Fac. Forestry, Univ. B.C., Vancouver.

Lee, W.-K., von Gadow, K., Chung, D.-J., Lee, J.-L., Shin, M.-Y, 2004. DBH growth model for Pinus densiflora and Quercus variabilis mixed forest in central Korea. Ecol. Model. 176, 187-200.

Lejeune, P., 1993. Exploitation d'un S.I.G pour la définition de variables écologiques utilisées pour modéliser la croissance de peuplements forestiers. Biom. Praxim. 33, 81-97.

Lorimer, C.G, 1983. Tests of age-independent competition indices for individual trees in natural hardwood stands. For. Ecol. Manage. 6, 343-360

Louw, J.H., Scholes, M.C., 2006. Site index functions using site descriptors for Pinus patula plantations in South Africa. For. Ecol. Manage. $225,94-103$

Mabvurira, D., Miina, J., 2002. Individual-tree growth and mortality models for Eucalyptus grandis (Hill) Maiden plantations in Zimbabwe. For. Ecol. Manage. 161, 231-245.

Marquardt, D.W., 1970. Generalized inverses, ridge regression, biased linear estimation, and nonlinear estimation. Technometrics 12, 591612.

Martin, G.L., Ek, A.R., 1984. A comparison of competition measures and growth models for predicting plantation red pine diameter and height growth. Forest Sci. 30, 731-743.

Mitchell, K.J., 1975. Dynamics and simulated yield of douglas-fir. Forest Sci. Monogr., 17.

Monserud, R.A., 1975. Methodology for simulating Wisconsin northern hardwood stand dynamics, Univ. Wisconsin-Madison, Dissertation Abstracts 36 (11).

Monserud, R.A., Sterba, H., 1996. A basal area increment model for individual trees growing in even- and uneven-aged forest stands in Austria. For. Ecol. Manage. 80, 57-80.

Nanson, A., 2004. Génétique et amelioration des arbres forestiers. Les Presses Agronomiques de Gembloux, Gembloux.

Newnham, R.M., 1964. The development of a stand model for Douglas-fir. Ph.D. Thesis. Fac. of Forestry, Univ. B.C., Vancouver.

Nitschke, C.R., Innes, J.L., 2008. A tree and climate assessment tool for modelling ecosystem response to climate change. Ecol. Model. 210, 263-277.

Ottorini, J.-M., 1991. Growth and development of individual Douglas-fir in stands for applications to simulation in silviculture. Ann. Sci. For. 48, 651-666

Pacheco Marques, C, 1991. Evaluating site quality of even-aged maritime stands in northern Portugal using direct and indirect measures. For. Ecol. Manage. 41, 193-204.

Pauwels, D., Lejeune, P., Rondeux, J., 2003. Modèle de croissance pour les plantations de mélèzes. Biotechnol. Agron. Soc. Environ. 7 (2), 87-97.

Poncelet, L., Martin, H., 1947. Esquisse climatographique de la Belgique. Mémoires, vol. XXVII. IRM, Bruxelles, p. 265.

Porte, A., Bartelink, H.H., 2002. Modelling mixed forest growth: a review of models for forest management. Ecol. Manage. 150, 141-188.

Pretzsch, H., 2002. Application and evaluation of the growth simulator silva 2.2 for forest stands, forestry enterprise and large regions. Forstwiss. Centralblatt 121 (Supplement 1), 28-51.

Pukkala, T, 1989. Predicting diameter growth in even-aged Scots pine stands with a spatial and non-spatial model. Silva Fennica 23 (2), 101116.

Rondeux, J., Pauwels, D., 1997. Le Forestor Vertex: une nouvelle generation de dendromètres. Rev. For. Fr. 49, 59-63.

Rondeux, J., Lecomte, H., 2001. L'inventaire forestier wallon. Rev. For. Fr. LIII, 263-267. Rondeux, J., Thibaut, A., 1996. Tables de production relatives au Douglas. Les Presses Agronomiques de Gembloux, Gembloux.

Rondeux, J., Laurent, C, Thibaut, A., 1991. Construction d'une table de production pour le Douglas (Pseudotsuga menziesii (MIRB.) FRANCO) en Belgique. Cah. For. Gembloux, Gembloux.

Schroder, J., Rodriguez Soalleiro, R., Vega Alonso, G, 2002. An age-independent basal area increment model for maritime pine trees in northwestern Spain. For. Ecol. Manage. 157, 55-64. 
Published in: Ecological Modelling (2008), vol.212, iss.3-4, pp.472-479

Status: Postprint (Author's version)

Soares, P., Tome, M., Skovsgaard, J.P., Vanclay, J.K., 1995. Evaluating a growth model for forest management using continuous forest inventory data. For. Ecol. Manage. 71, 251-265.

Sterba, H., Monserud, R.A., 1997. Applicability of the forest stand growth simulator PROGNAUS for the Austrian part of the Bohemian Massif. Ecol. Model. 98, 23-24.

Tome, M., Burkhart, H.E., 1989. Distance-dependent competition measures for predicting growth of individual trees. Forest Sci. 35, 816831 .

Vanclay, J.K., 1994. Modelling Forest Growth and Yield: Applications to Mixed Tropical Forests. CAB International, Wallingford, UK. Van Laar, A., 1991. Forest Biometry. University of Stellenbosch, South Africa.

Veron, P., Bah, B., Bracke, C, Lejeune, P., Rondeux, J., Bock, L., Mokadem, A.I., 2005. The digital soil map of Wallonia (DSMW/CNSW). In: Proceedings of XXII International Cartographic Conference at A Coruña, July 11-16, 2005, p. 8.

Wimberly, M.C., Bare, B.B., 1996. Distance-dependent and distance-independent models of Douglas-fir and western hemlock basal area growth following silvicultural treatment. For. Ecol. Manage. 89,1-11.

Wykoff, W.R., Crookston N.L., Stage A.R., 1982. User's guide to the stand prognosis model. General Technical Report INT-133. USDA Forest Service, Intermountain Forest and Range Experiment Station, Ogden, UT.

Wykoff, W.R., 1986. Supplement to the user's guide for the Stand Prognosis Model—version 5.0. General Technical Report INT-208. USDA Forest Service, Intermountain Forest and Range Experiment Station, Ogden, UT.

Zhang, Q.B., Hebda, R.J., Zhang, Q.J., Alfaro, R.I., 2000. Modelling tree-ring growth responses to climatic variables using artificial neural networks. Forest Sci. 46 (2), 229-239. 